\title{
Impact of Deposit Rate Deregulation in Hong Kong on the Market Value of Commercial Banks
}

\author{
Simon H. Kwan \\ Federal Reserve Bank of San Francisco \\ Hong Kong Institute for Monetary Research
}

This draft: April, 2002

Please do not quote without permission

\begin{abstract}
This paper examines the effects of a series of events leading up to the deregulation of deposit interest rates in Hong Kong on the market value of banks. All the evidence suggests that banks earned rents from deposit interest rate rules and deregulation would lower these rents and hence bank market values. On average, the total abnormal return due to interest rates deregulation was around negative $4 \%$. There is some evidence that large banks and banks with high deposit-to-asset ratio suffered a bigger drop in value, suggesting that these banks enjoyed a bigger subsidy under the interest rate rules.
\end{abstract}

JEL Classification: G21, G28

Keywords: Deposit rate deregulation, Interest rate rules, Hong Kong banks

Please send correspondence to Simon Kwan, Economic Research, Federal Reserve Bank of San Francisco, 101 Market Street, San Francisco, CA 94105, U.S.A.

Telephone: 415-974-3485; Fax: 415-974-2168; E-mail: simon.kwan@sf.frb.org

This research was conducted while I was visiting the Hong Kong Institute for Monetary Research. Helpful comments from two anonymous referees, Guy Meredith, Raymond $\mathrm{Li}$, Yin-Wong Cheung, and seminar participants at the Hong Kong Monetary Authority are gratefully acknowledged. The views expressed in this paper are the author's only and do not represent the views of the Federal Reserve Bank of San Francisco, the Federal Reserve System, the Hong Kong Institute for Monetary Research, or the Hong Kong Monetary Authority. Emily Cheng provides excellent research assistance. All remaining errors are mine. 


\section{Impact of Deposit Rate Deregulation in Hong Kong on the Market Value of Commercial Banks}

\section{Introduction}

The regulation of interest rates paid to bank depositors represents one form of government intervention in the financial market that may lead to misallocation of funds.

In the last two decades, policy makers in countries with deposit rate regulations have started to relax those restrictions in order to limit or eliminate such distortions, from big countries like the U.S. to small city-states like Hong Kong. The deregulation of deposit interest rates in the U.S. has been studied extensively in the banking literature. For example, Dann and James (1982) found that stockholder-owned savings and loan associations (S\&Ls) experienced statistically significant declines in equity market values at the announcement of the removal of rate ceilings on certain consumer certificate accounts and the introduction of short-term variable rate money market certificates, suggesting that S\&Ls had earned economic rents from interest rate restrictions. MillonCornett and Tehranian (1989) studied the effects of the passage of the Depository Institutions Deregulation and Monetary Control Act of 1980 on bank shareholders' wealth; they found that small bank stocks experienced negative abnormal returns, while large bank stocks incurred significantly positive abnormal returns, suggesting that the Act resulted in an intra-industry wealth transfer. However, studies of interest rate deregulation in other countries are relatively few, and to my knowledge none exists for the case of Hong Kong which is considered an important international financial center.

This paper examines the effects of deposit interest rate deregulation in Hong 
Kong on bank equity values. Hong Kong has been well known for its laissez-faire economy. It has a highly competitive banking environment, with over 150 licensed banks in a city with only 1,100 square kilometers of land area. Furthermore, Hong Kong banks in general have a much higher deposit-to-asset ratio, averaging about $80 \%$ in 1999 , than commercial banks in the U.S., which averaged only about $65 \%$. Hence, given the somewhat different industrial organizational structure and balance sheet compositions among Hong Kong banks, it would be of interest to find out whether the effects of interest rate deregulation on Hong Kong banks were similar to those experienced in the U.S.

Since 1964, interest rates on bank deposits in Hong Kong have been regulated by a set of interest rate rules (IRRs) issued by the Hong Kong Association of Banks (HKAB) under the HKAB Ordinance. The IRRs originally applied to interest rates paid by licensed banks to customers on Hong Kong dollar (HK\$) deposits of less than $\$ 500,000$ and with a maturity of less than 15 months. ${ }^{1}$ Under the IRRs, no interest is paid on current accounts. Interest rates on other accounts covered by the IRRs are determined from time to time by the HKAB Committee after consultation with the Hong Kong Monetary Authority (HKMA) under delegated authority from the Financial Secretary of Hong Kong. The IRRs were in full operation until 1994, when the rules were first relaxed by removing the interest rate cap on certain types of time deposits. In May 2000,

\footnotetext{
${ }^{1}$ Specifically, the IRRs set rates on the following accounts: (a) current accounts (same as demand deposits); (b) savings accounts; (c) 24-hour call deposits; (d) 7-day call deposits; and (e) time deposits up to 15 months in maturity.
} 
after the sovereignty of Hong Kong had been returned to China in 1997, and after the local economy had recovered from the Asian financial crisis, the HKMA announced steps to abolish the IRRs entirely.

This paper tests three hypotheses about the effects of deregulating deposit interest rates on bank equity values. The first hypothesis is the Subsidy Reduction Hypothesis. It holds that setting deposit rates by a formal cartel, as was the case of Hong Kong, rather than by market forces, may confer monopoly rents upon banking institutions. This argument generally proceeds as follows. Some suppliers of capital restrict their choice of investment medium for at least a portion of their wealth to bank deposits, for a number of reasons including risk aversion, convenience, and lack of sufficient resources to meet minimum initial investment requirements elsewhere. Constraining deposit rates to a level below which banks would be willing to pay in an otherwise free market subsidizes banks at the expense of depositors. Moreover, by limiting the value of other services that banks can offer, the cartel assures that the subsidy arising from restricting price competition is not fully dissipated via non-price competition. Under this argument, a relaxation of the IRRs reduces the subsidy to the bank, and by implication the value of the bank. ${ }^{2}$

Second is the Irrelevance Hypothesis. It holds that any subsidies banks might receive from restricting price competition are fully dissipated through non-price

\footnotetext{
${ }^{2}$ The existence of monopoly rents that arise from restricting competition among banks does not by itself ensure that these rents augment the value of the institution. The rents may be captured by managers of banks in the form of supracompetitive salaries and other perquisites. It is assumed that the market for managers in Hong Kong is sufficiently competitive that at least some of the rents accrue to the owners of the banks.
} 
competition, such as providing subsidized banking services or other non-monetary benefits, operating longer hours, and building a larger branch network. Under this view, depositors essentially receive the equivalent of the full-market interest rate. This hypothesis predicts that the deregulation of interest rates will have no impact on the value of banks.

A third hypothesis is a variant of the Producer Protection Hypothesis originally posited by Stigler (1971) and Jordan (1972). In his "capture" theory of regulation, Stigler proposes that although regulators are originally established by the government to regulate the regulatees, they can be subsequently "captured" by the regulatees due to the alignment of self-interests between the two. For example, both the regulators and the regulatees may have the same incentive to maximize the size of the regulated industry. Hence, according to this theory, regulation is demanded and acquired by the regulated, and regulations are designed and administrated primarily for the benefits of the regulatees. ${ }^{3}$

In the case of the IRRs, the relaxation of interest rate ceiling on deposits may prevent disintermediation from banks that would otherwise occur. Furthermore, banks in Hong Kong had developed certain substitutes for regulated deposits, including foreign currency swap deposits, which are not subject to the IRRs. Foreign currency swap

\footnotetext{
${ }^{3}$ We distinguish between the effects of the original imposition of government regulation and the subsequent administration of the regulations. Imposing regulations on a previously unregulated firm may reduce firm value, but it does not necessarily follow that all subsequent regulatory actions will be value-reducing. Peltzman (1976) argues that the regulators' constituency cannot in general be limited to one economic interest. Hence, it is important to emphasize that the issue addressed in this paper is whether the regulated industry on balance benefits from regulatory changes in deposit rate ceilings.
} 
deposits are deposits involving customers buying foreign currencies in the spot market and placing them as deposits with banks while at the same time entering into a contract to sell such foreign currencies (principal plus interest) forward in line with the maturity of such deposits. To the extent that these foreign currency swap deposits are more costly to produce than regulated domestic deposits, removing the interest rate ceilings may help banks to save on operating costs. Finally, if close substitutes for regulated deposits are not readily available, competing through non-price channels for deposits may be less efficient and more costly than unfettered competition. Under the Producer Protection Hypothesis, relaxing the IRRs would not harm banks' earnings but would permit them to compete more effectively with unregulated financial instruments and to operate more efficiently. This hypothesis predicts that the relaxation of the IRRs will add value to banks.

A series of events (to be discussed in the next section) took place between 1994 and 2000 that led to the ultimate deregulation of the IRRs. In this paper, the effect of the IRRs deregulation on returns to shareholders of publicly held commercial banks in Hong Kong is examined. Specifically, the abnormal return to shareholders due to each new piece of information concerning the deregulation is measured using the generalized least squares (GLS) estimation.

The rest of the paper is organized as follows. Section II describes the chronological development of the IRRs deregulation in Hong Kong. The methodology and data are discussed in Section III. Results of the event study are presented in Section IV. Section V concludes this paper. 


\section{IRRs Deregulation}

Table 1 provides the key event dates associated with the deregulation of deposit interest rate ceilings in Hong Kong which span a six-year period. It can be described as a two-stage process that is neatly separated by the 1997 takeover of Hong Kong by China. Stage one of the deregulation occurred between 1994 and 1995 when Hong Kong was still a British colony. The second stage took place between 1998 and 2000 after the sovereignty of Hong Kong was returned to China.

\section{A. Stage One}

On February 28, 1994, the Consumer Council in Hong Kong, a government agency, released a Report entitled “Are Hong Kong Depositors Fairly Treated?" (the Report). It was based on a consultancy study commissioned by the Consumer Council to evaluate the impact of banking policies and practices on the consumer. Throughout the Report, it focuses on the effects of the IRRs on consumer welfare. The Report concluded that licensed banks in Hong Kong, by operating as a cartel, had been extracting excess profits from depositors through setting artificially low deposit interest rates under the IRRs. The Report estimated the rent earned by Hong Kong banks due to the IRRs to be on the order of $1 \%$ of Hong Kong's GDP annually. ${ }^{4}$ The Consumer Council thus recommended a gradual phasing out of all the IRRs commencing in 1995. Because this recommendation was made by an agency of the Hong Kong government, for the first time in more than thirty years, the IRRs faced the possibility of being abolished in the future. While there were big uncertainties about whether, and how, the deregulation

${ }^{4}$ Please also see Chan and Khoo (1998) for the academic version of the paper. 
would eventually take place, this announcement was widely perceived as the watershed event that could greatly undermine the operation of the banking cartel.

Not surprisingly, the HKAB disagreed with the Consumer Council's recommendation to phase out the IRRs and denied the Report's assertion of a monopsonistic deposit market in Hong Kong. After studying the Consumer Council's Report and conducting its own research, the HKMA, the de facto central bank and the sole banking regulator in Hong Kong, issued an official response to the IRRs Report on July 4, 1994. The HKMA found no conclusive evidence that the banks were reaping excessive profits from the IRRs. Furthermore, while the IRRs created the potential for monopsonistic profits, the HKMA was not convinced by the Report's estimates of the size of the rents. In particular, the HKMA pointed out that the potential for excess profits would have been eroded by the development of substitutes for IRR-regulated deposits, such as the development of swap deposits. The use of non-price competition, and the lack of significant disintermediation were also cited as counter arguments to the existence of monopsony profit in the banking industry.

While not accepting all the arguments put forth by the Report, the HKMA, a proponent of the free market philosophy, encouraged the liberalization of the way in which retail interest rates were set in Hong Kong. The HKMA proposed a partial removal of the interest rate cap on time deposits in 1995. This reflected the fact that HK\$ time deposits subject to the IRRs were only about $4 \%$ of total HK\$ deposits at that time, and such deposits already faced competition from swap deposits. Regarding demand deposits and savings deposits, which were much more significant in size, the 
HKMA's position was that deregulation would be considered only when the impact of the time deposit deregulation had been fully assessed.

In rejecting the Report's conclusion, the HKMA's response seemed to reduce the probability of a full-scale deregulation that was recommended by the Consumer Council. Nevertheless, the HKMA was under strong public pressure to deregulate the IRRs, especially when the public support for a free and open market economy ran high during the years immediately before the Chinese takeover of Hong Kong. The proposition by the HKMA to only partially deregulate the less significant time deposits while leaving the demand and savings deposits intact could be viewed as a compromise to satisfy public opinion while protecting banks from a full deregulation. More importantly, to the extent that Hong Kong banks had developed foreign currency swap deposits to substitute for regulated time deposits, the selective deregulation of time deposits may reduce banks' production costs without changing the profitability of other deposits.

On July 26, 1994, the Hong Kong government officially adopted the HKMA's study in response to the Consumer Council's report on the IRRs, setting the stage for deregulating time deposits with a maturity of more than 24 hours. In the first phase of deregulation, the interest rate cap on time deposits with maturity of more than one month was lifted. The second phase deregulated time deposits with a maturity of more than seven days; and the final phase deregulated time deposits with a maturity of more than 24 hours. The government also explicitly stated that the HKMA was not considering the deregulation of other deposits at that time. While the deregulation of more than 24 hours time deposits was largely anticipated following the last HKMA announcement, the news 
content of this announcement lies on the confirmation by the government that no further deregulation was being considered at that time.

On August 26, 1994, following discussions with the HKMA, the HKAB announced a program for the removal of time deposits from the IRRs starting from October of that year. According to the timetable, interest rates on all deposits fixed for more than 24 hours would be freed by April 1, 1995. As for 24-hour call deposits, deregulation would be phased in gradually by removing the deposit cap during the rest of 1995, subject to the condition that both the HKMA and the HKAB were satisfied that the stability of the monetary and banking systems would not be undermined. This event, at that time, finalized the partial deregulation of the IRRs.

After implementing the first two phases of time deposit deregulation, on March 14, 1995, the HKMA announced the decision to postpone the third phase of deregulation of time deposits fixed for more than 24 hours, due to potential instability in the banking sector. This event rolled back some of the deregulation initiatives that were finalized in the previous announcement.

On September 26, 1995, the Hong Kong government announced the decision to remove the interest rate cap on time deposits fixed for seven days. The government also decided that there should be no further deregulation of time deposits with a maturity of less than seven days and that the current program of deregulation should come to an end, in order to strike a balance between preserving banking stability and introducing more competition. This event further rolled back the scale of the time deposit deregulation that was announced earlier. More significantly, this announcement removed the probability 
of further deregulation in the near term.

\section{B. Stage Two}

Almost three years later in March 1998, after China regained Hong Kong's sovereignty, the HKMA appointed two consulting firms to study the future development of the banking sector in Hong Kong. Six months later, on December 18, 1998, the study, "Hong Kong Banking into the New Millennium," was released to the public. The study made a number of important policy recommendations, including the multi-phased deregulation of the remaining IRRs in Hong Kong. Unfortunately, this is not a clean announcement in the sense that other banking policy recommendations were also made by the consulting firms in the same study, thus contaminating the event of focus.

Furthermore, the recommendations were those of the consultants and that the HKMA had not taken any position on the recommendations. Nevertheless, this event resurrected the prospect for deregulating the remaining IRRs.

On July 14, 1999, after a three-month public consultation period, the HKMA issued a policy response to the recommendations of the consultancy study. One of the initiatives was to adopt a two-phased approach to deregulating the remaining IRRs, provided that economic and financial conditions were favorable for deregulation after extensive monitoring of the economy. While this announcement conveyed to the public the intention of the government to deregulate the remaining IRRs, there was a fair amount of uncertainty regarding the future condition of the economy as Hong Kong was recovering from the Asian financial crisis. The lack of any concrete steps to remove the remaining IRRs reduced the probability that the IRRs would be phased out in the near 
future.

On May 30, 2000, the HKMA announced the deregulation of the remaining time deposits with a maturity of less than 7 days. More significantly, it also announced that the interest rate caps on demand and savings deposits would be removed in July 2001. Successful implementation of these two phases of interest rate deregulation would completely abolish the 36-year-old IRRs.

This was a significant announcement because as of 1999, total HK\$ demand and savings deposits accounted for $32 \%$ of total HK\$ deposits held by licensed banks. Back in 1994 when time deposits were partially deregulated, HK\$ time deposits subject to the IRRs constituted only $4 \%$ of HK\$ deposits. Thus, compared to the deregulation of time deposits, the deregulation of demand and savings deposit rates represented a much more important economic event. Furthermore, this was a very "clean" event because the announcement pertained only to the IRRs deregulation and was free from information contamination.

\section{Methodology and Data}

Following the standard event study methodology to determine the effects of regulatory changes on shareholders' wealth, this paper adopts the multivariate regression approach based on Zellner's (1962) seemingly unrelated regression model. The system of equations conditions the return-generating process on the occurrence or nonoccurrence of an event by including dummy variables. The estimated coefficient of the dummy variable, which equals one if an event occurred and zero otherwise, measures the 
effect of the event on bank stock returns. This regression approach has been used extensively in the literature to study the effects of regulatory changes on stock returns [see, for example, Binder (1985), Saunders and Smirlock (1987), Millon-Cornett and Tehranian (1989), Sundaram, Rangan, and Davidson (1992), and Bhargava and Fraser (1998)].

Following the studies on financial institutions' stock returns [see, for example, Flannery and James (1984), Kwan (1991), and Song (1994)], the return generating process for bank stock returns is the two-factor model, where the two factors are the market index and the interest rate index. Adding the interest rate factor to the singlefactor market model has been shown to improve the explanatory power for bank stock returns. Following Sundaram et al. (1992) and Bhargava and Fraser (1998), both the market beta and the interest rate beta are allowed to shift after the conclusion of the deregulation in each stage. Furthermore, following Saunders and Smirlock (1987) and Bhargava and Fraser (1998), lagged market return and lagged interest rate change are included in the model to account for nonsynchronous trading. Equation (1) depicts the empirical model to test the effects of interest rate deregulation in Hong Kong on banks' stock returns:

$$
\begin{aligned}
\mathrm{R}_{\mathrm{jt}}=\alpha_{1 \mathrm{j}} & +\alpha_{2 \mathrm{j}} \mathrm{D}_{0}+\beta_{1 \mathrm{j}} \mathrm{R}_{\mathrm{m}, \mathrm{t}}+\beta_{2 \mathrm{j}} \mathrm{R}_{\mathrm{m}, \mathrm{t}} \mathrm{D}_{0}+\beta_{3 \mathrm{j}} \mathrm{R}_{\mathrm{m}, \mathrm{t}-1}+\beta_{4 \mathrm{j}} \mathrm{R}_{\mathrm{m}, \mathrm{t}-1} \mathrm{D}_{0} \\
& +\beta_{5 \mathrm{j}} \mathrm{R}_{\mathrm{i}, \mathrm{t}}+\beta_{6 \mathrm{j}} \mathrm{R}_{\mathrm{i}, \mathrm{t}} \mathrm{D}_{0}+\beta_{7 \mathrm{j}} \mathrm{R}_{\mathrm{i}, \mathrm{t}-1}+\beta_{8 \mathrm{j}} \mathrm{R}_{\mathrm{i}, \mathrm{t}-1} \mathrm{D}_{0}+\sum_{\mathrm{k}} \gamma_{\mathrm{jk}} \mathrm{D}_{\mathrm{k}}+\epsilon_{\mathrm{jt}},
\end{aligned}
$$

where

$\mathrm{R}_{\mathrm{jt}}$ is jth bank's stock return at day $\mathrm{t}$;

$\mathrm{R}_{\mathrm{mt}}$ is the return on the equally weighted market portfolio at day $\mathrm{t}$; 
$\mathrm{R}_{\mathrm{it}}$ is the relative change in the 12-month Hong Kong Interbank Offer Rate from day t-1 to day $\mathrm{t}$;

$D_{k}$ is a dummy variable that equals one if the kth event occurred and zero otherwise;

$\mathrm{D}_{0}$ is a dummy variable that equals one after the deregulation process is completed in each stage and zero otherwise;

$\alpha_{1 \mathrm{j}}$ and $\alpha_{2 \mathrm{j}}$ are intercept terms before and after deregulation;

$\beta_{1 \mathrm{j}}$ and $\beta_{2 \mathrm{j}}$ are systematic risk coefficients on market return;

$\beta_{3 \mathrm{j}}$ and $\beta_{4 \mathrm{j}}$ are systematic risk coefficients on lagged market return;

$\beta_{5 \mathrm{j}}$ and $\beta_{6 \mathrm{j}}$ are interest rate risk coefficients on interest rate change;

$\beta_{7 \mathrm{j}}$ and $\beta_{8 \mathrm{j}}$ are interest rate risk coefficients on lagged interest rate change;

$\gamma_{\mathrm{jk}}$ is the wealth effect of event k on the jth bank's stock;

$\epsilon_{\mathrm{jt}}$ is the disturbance term for bank $\mathrm{j}$ on day $\mathrm{t}$.

The coefficient $\gamma_{\mathrm{jk}}$ of the dummy variable $\mathrm{D}_{\mathrm{k}}$ measures the abnormal return on the jth bank's stocks due to event k. Since the Hong Kong government follows the tradition of announcing news that could potentially move the market after the stock market close, the event window is the first trading day following the announcement date. ${ }^{5}$

Due to the fact that the series of news announcements related to the IRRs deregulation had different implications on the actual removal of the deposit rate ceilings, the coefficients of the event dummies may have different signs under the same hypothesis. Specifically, while the 2-28-1994 release of the Report raised the issue of

${ }^{5}$ Using a two-day event window that includes day -1 and day 0 of the event produces qualitatively similar results, which are available upon request. 
phasing out all the IRRs, the subsequent response by the HKMA on 7-4-1994 and the government action on 7-26-1994 reduced the chance of a full scale deregulation.

Whereas the 8-26-1994 HKAB announcement set forth the motion to deregulate time deposits, the postponement on 3-14-1995 set back the deregulation; and the termination of the deregulation program on 9-26-1995 reduced the likelihood of a total phasing out of the IRRs in the near term to zero.

In the second stage of deregulation, while the 12-18-1998 release of the commissioned study resurrected the chance of deregulating the remaining IRRs, the 714-1999 policy initiative by the HKMA reduced this probability in the near term. Finally, the 5-30-2000 announcement basically laid out the plan to demolish all remaining IRRs entirely. Thus, in interpreting the coefficients for different events, it is important to refer to the original news announcements in testing the competing hypotheses.

Using the above regression framework to test the proposed hypotheses has a number of advantages. As pointed out by Schipper and Thompson (1983), the multivariate regression method is efficient in event studies where there are (1) multiple announcements of information during the period of regulatory change; (2) high crosssectional correlation in stock returns due to event clustering; and (3) relatively small sample size. All three conditions are met in this study.

While there were 156 licensed banks in Hong Kong at the end of 1999, 97 of them were single-office, wholesale financial institutions that did not engage in retail deposit taking. Almost all of these wholesale institutions were branches or representative 
offices of foreign banks that established a presence in this Asian financial center. Of the remaining 59 multi-branch banks, 46 were wholly owned subsidiaries of foreign financial institutions, including the Bank of China group of banks and the U.K. based Standard Chartered Bank that had a significant retail presence in Hong Kong. This left only 13 locally incorporated commercial banks whose revenues derived largely from their Hong Kong operations. All of the 13 Hong Kong banks were publicly held and their common stocks were traded in the Hong Kong Stock Exchange. ${ }^{6}$ These 13 listed banks, including some of the largest institutions in Hong Kong, together accounted for $48 \%$ of all deposits held by licensed banks in 1999. Appendix 1 provides the name of the sample banks.

Descriptive statistics for the sample banks as of 1999 are shown in Table 2. The average bank in the sample had total assets of \$201 billion Hong Kong Dollars. However, the standard deviation of total assets was large, indicating that the sample consists of a few very large banks and a number of relatively small institutions. On average, the sample Hong Kong banks had a fairly high $81 \%$ deposit-to-asset ratio, with relatively less cross-sectional variation in this ratio than exhibited in total assets. The net interest margin, defined as the ratio of net interest income to total earning assets, averaged $2.61 \%$ and also exhibited relatively little cross-sectional variation. It is unclear whether the interest rate rules, which remained effective for the bulk of Hong Kong dollar deposits in 1999, had anything to do with the almost constant net interest margin across banks. The mean five-year compound average growth rates for deposits and loans were about $80 \%$, with a $31 \%$ standard deviation. The observation that on average, loan

${ }^{6}$ Hong Kong did not have an over-the-counter stock market. 
growth was funded almost entirely by deposit growth was quite remarkable, suggesting the importance of deposits in the banking industry. Together with the relatively high deposit-to-asset ratio, the deregulation of deposit interest rates in Hong Kong appeared to be a very important economic event to the Hong Kong banking sector.

In using equation (1) to examine the wealth effects of the interest rates deregulation on bank stocks, the abnormal return, measured by the coefficient $\gamma_{\mathrm{jk}}$, is allowed to vary cross-sectionally as different bank stocks might respond differently to the deregulation. Since Table 2 shows that there was a substantial cross-sectional variation in bank characteristics across the sample, it would be of interest to test whether the magnitude of the abnormal return is directly proportional to certain bank characteristics. The two most obvious candidates seem to be the bank size and the deposit-to-asset ratio. ${ }^{7}$ First, to the extent that a large bank might have a bigger influence on both the banking cartel and the regulatory process, the abnormal return might be proportional to bank size. Second, more specifically, since the deregulation pertained to a bank's deposit taking activities, the abnormal return therefore might be directly related to the deposit-to-asset ratio. To test whether the magnitude of the abnormal return is proportional to bank characteristics, equation (1) is modified to condition the abnormal return on either bank size or the deposit-to-asset ratio:

$$
\begin{aligned}
R_{j t}=\alpha_{1 j} & +\alpha_{2 j} D_{0}+\beta_{1 j} R_{m, t}+\beta_{2 j} R_{m, t} D_{0}+\beta_{3 j} R_{m, t-1}+\beta_{4 j} R_{m, t-1} D_{0} \\
& +\beta_{5 j} R_{i, t}+\beta_{6 j} R_{i, t} D_{0}+\beta_{7 j} R_{i, t-1}+\beta_{8 j} R_{i, t-1} D_{0}+\sum_{k} \gamma_{j k} X_{j t} D_{k}+\epsilon_{j t}
\end{aligned}
$$

${ }^{7}$ It should be noted that for the sample banks, bank size and the deposit-to-asset ratio are positively correlated. 
where

$\mathrm{X}_{\mathrm{jt}}$ is either the $\log$ of total assets or the deposit-to-asset ratio of the jth bank at time $\mathrm{t}$. If the abnormal return in equation (1) is directly proportional to bank size or the deposit ratio, the $\gamma_{\mathrm{jk}}$ in equation (2) is expected to be constant across banks. The F-test is used to test the hypothesis that $\gamma_{\mathrm{jk}}$ in (2) is constant, taking cross-correlation in $\epsilon_{\mathrm{jt}}$ into consideration. Failure to reject the hypothesis that $\gamma_{\mathrm{jk}}$ is constant across banks in equation (2) suggests that the abnormal return is systematically related to bank characteristics.

Daily stock returns for all 13 listed banks in Hong Kong are obtained from the Bloomberg terminal to estimate the empirical model. ${ }^{8}$ The daily returns of the Hang Seng Stock Index are used to proxy for the market return. The relative change in the 12month Hong Kong Interbank Offer Rate (HIBOR) is used as the interest rate index. ${ }^{9}$ To study the effects of the first stage of the interest rate deregulation on bank values, daily data from September 1993 to October 1995 are used to fit the model. For the effects of the second stage deregulation, the model is estimated using daily data from July 1997 to June 2000. Before fitting the model, the South China Morning Post, the leading English language newspaper in Hong Kong, was searched for contaminating events on the event date and two business days on either side of the event date that also may have affected bank stock returns. If potentially contaminating news was found for a particular sample

8 Stock returns for one of the sample banks were not available to estimate the events on 2-28-1994 and 7-4-1994 listed in Table 1.

9 The results are robust to alternative specifications of the interest rate index. Using the 1-month HIBOR to construct the interest rate index provides similar results. 
bank around the event dates in Table 1, the bank in question was removed from the sample for that event date. ${ }^{10}$ The model is estimated by GLS using the seemingly unrelated regression approach with daily data separately for Stage One and Stage Two of the IRRs deregulation. The results are discussed in the next section.

\section{Empirical Results}

Table 3 presents the results of estimating the model for the first stage of the deregulation. Except for the last column, the findings in Table 3 are obtained from estimating equation (1) where the abnormal return is unconditional on bank characteristics. Column one provides the event number, the event date, and a short description of the event. Column two is the cross-sectional mean of the coefficient of the dummy variable for the sample banks. The t-statistic testing the hypothesis that the mean of the dummy coefficient equals zero is in column three. Column four is the median estimate of the event dummy across banks, and the non-parametric signed-rank statistic testing the sign of the dummy coefficient is in column five. Note that both the t-test and the signed-rank test assume that the coefficient estimates are distributed independently across banks. To the extent that this assumption may not hold due to event clustering, column six shows the F-statistic testing the hypothesis that the dummy coefficients across individual banks jointly equal zero, taking full consideration of all the crosscorrelation in stock returns across banks. Finally, the last column in Table 3 presents the

10 There were only two cases of potential news contamination: two sample banks announced their quarterly earnings on 9-25-1995. 
results of testing the hypothesis that $\gamma_{\mathrm{jk}}$ is constant across banks after controlling for bank size, as depicted in equation (2). Conditioning the abnormal return on the deposit-toasset ratio yields qualitatively similar results, which are not reported here.

The average abnormal bank stock return following the 2-28-1994 public release of the Consumer Council Report was negative 1.71\%, and the median abnormal return was negative $1.47 \%$. While the t-statistic is marginally significant, the signed-rank statistic is not. More importantly, the F-statistic is highly significant at the $1 \%$ level. Thus, the results suggest that this event had a significantly negative effect on bank stock returns, which lends support to the Subsidy Reduction Hypothesis. The evidence suggests that investors were bidding down bank stocks in anticipation of potential interest rates deregulation in the future upon the release of the Report.

With respect to the second and the third events when the HKMA officially rejected the Report's conclusion and the Hong Kong government adopted a more measured approach towards deregulating the IRRs, both the mean and the median abnormal returns were positive, albeit statistically insignificant. The positive coefficients also are consistent with the Subsidy Reduction Hypothesis that market participants were revising downward the probability of deregulating all deposit interest rates in Hong Kong following the government's response.

The first official action of relaxing the IRRs on time deposits on 8-26-1994 resulted in an average abnormal return of negative $0.13 \%$, and the F-test is statistically significant. While providing further support to the Subsidy Reduction Hypothesis, the small negative abnormal returns seemed to be due to the fact that only a very small 
fraction of deposits would be affected by this decision. Notice that the sum of abnormal returns due to the first four events, as reported in row 7 , averaged negative $0.60 \%$ and is statistically significant. This can be interpreted as the market's reaction to the deregulation of time deposits and the expectation of future deregulation of other deposits. ${ }^{11}$

Regarding the last two events when the Hong Kong government first postponed and then terminated IRRs deregulation, the average abnormal returns for both events were positive, although not statistically significant. The sum of abnormal returns due to these two events averaged $1.10 \%$, as reported in row 8 . The positive signs of the abnormal returns are consistent with the Subsidy Reduction Hypothesis that postponing and terminating the deregulation would preserve whatever subsidies due to the remaining IRRs to banks.

To gauge the total effects of the first stage of interest rates deregulation on bank values, row 9 in Table 3 shows that the total abnormal return due to all six events averaged $0.50 \%$ and was insignificantly different from zero. The insignificant total abnormal return perhaps was due to the fact that only a small fraction of deposits ended up deregulated in this stage. However, all six individual events had mean and median abnormal returns exhibiting the sign pattern as expected under the Subsidy Reduction Hypothesis. Under the null hypothesis that each mean abnormal return had equal chance of being positive or negative, the probability of all six mean abnormal returns demonstrating the expected signs is only $1.56 \%$. Thus, taken together, the findings in

${ }^{11}$ Thanks are due to an anonymous referee for suggesting this interpretation. 
Table 3 seem to provide empirical support for the Subsidy Reduction Hypothesis.

Turning to the last column in Table 3, the hypothesis that the abnormal return (or the sum of the abnormal returns) was directly proportional to bank size is rejected in all three instances where the abnormal returns (or the sum of abnormal returns) were significant. Similar findings are obtained when the conditioning variable is replaced by the deposit-to-asset ratio. It appears that the magnitude of the bank specific abnormal return in stage one cannot be fully explained by either bank size or the deposit-to-asset ratio, although the somewhat small abnormal returns registered in this stage may make such a relationship difficult to detect.

Table 4 presents the results for the second stage of interest rates deregulation. The 12-18-1998 public release of the commissioned study, which, among other things, recommended the deregulation of the remaining IRRs, is found to result in an average abnormal return of negative $2.02 \%$ and a median abnormal return of negative $2.14 \%$. While both the t-test and the signed-rank test suggest that the abnormal return is significant, the F-test does not. The insignificant F-test seems to indicate that crosssectionally, different bank stocks reacted to the information differently. This may be caused by news contamination as the released commissioned study covered not only interest rates deregulation but also other areas of banking. Nevertheless, both the mean and the median abnormal returns were economically large, and their signs were consistent with the Subsidy Reduction Hypothesis.

The mean and median abnormal returns associated with the 7-14-1999 HKMA response, which failed to put forth any concrete steps to deregulate the remaining IRRs, 
were $1.34 \%$ and $1.06 \%$, respectively. Again, while both the t-test and the signed-rank test suggest that the abnormal return was significant, the F-statistic is insignificant. The positive signs are consistent with the Subsidy Reduction Hypothesis as the market revised downward the probability of deregulating the remaining IRRs in the near future.

Finally, the announcement on 5-30-2000 by the HKMA to set forth the deregulation of the remaining time deposits, savings deposits, and demand deposits elicited an average abnormal return of negative $3.34 \%$ among the sample banks, with the median abnormal return at negative $3.61 \%$. The economically large abnormal returns were also statistically significant. Not only are both the t-statistic and the signed-rank statistic significant, but also the F-test is significant at the 5\% level. Once again, the findings are consistent with the Subsidy Reduction Hypothesis that banks earned rents under the IRRs and the relaxation of the rules reduced those rents. Notice that the probability of the sign pattern of all three events to be in complete agreement with the expected sign pattern under the Subsidy Reduction Hypothesis is $12.5 \%$.

Row 5 of Table 4 shows that the total abnormal return over the last three events averaged negative $4.01 \%$. The large abnormal returns were consistent with the economic significance of the events happening in this stage, which involved the deregulation of the more important demand and savings deposits.

Finally, the last column in Table 4 shows that the F-test fails to reject the hypothesis that the abnormal returns in stage two were proportional to bank size. Similar results are obtained for the deposit-to-asset ratio (not shown). The findings suggest that large banks (and banks with high deposit-to-asset ratio) suffered a bigger drop in bank 
value due to deregulation, suggesting that these banks earned a larger subsidy under the IRRs. One caveat is that this particular piece of finding may not be robust, since a similar relation was not detected in stage one. The much bigger abnormal return in stage two may make it easier to detect such a relationship.

\section{Conclusions}

This paper examines the effects of a series of events leading up to the deregulation of deposit interest rates in Hong Kong on bank shareholders' wealth. The deregulation of interest rates in Hong Kong took place in two stages spanning over six years that were separated by the return of Hong Kong to China. During the first stage, the unfolding developments provided a good opportunity to study how the market reacted to new information concerning interest rates deregulation. Although the end result in this stage was that only a small fraction of the total deposit base was freed from the IRRs, all the evidence suggests that banks earned rents under the IRRs and news about potential relaxation of the rules lowered bank values.

After the sovereignty of Hong Kong was returned to China, a series of events led the new Hong Kong government to abolish the 36-year-old IRRs completely. Compared to the first stage, these were more significant economic events as the IRRs on the more important demand and savings deposits would be removed. On average, bank stocks were found to suffer a total abnormal return of around negative 4\%. The significant decline in bank market values due to the interest rates deregulation confirms that the IRRs subsidized bank earnings at the expense of depositors. Removal of deposit rate 
restrictions would lower bank profits and hence bank shareholders' wealth.

Finally, there is some evidence that the effects of the interest rates deregulation on bank stock returns were proportional to bank size and the deposit-to-asset ratio. The results suggest that large banks and banks with high deposit-to-asset ratio earned a larger subsidy under the IRRs than small banks and banks with relatively less deposits. 


\section{References}

Bhargava, R. and D. R. Fraser, 1998, On the Wealth and Risk Effects of Commercial Bank Expansion into Securities Underwriting: An Analysis of Section 20 Subsidiaries, Journal of Banking and Finance 22, 447-465.

Binder, J.J., 1985, Measuring the Effects of Regulation with Stock Price Data, Rand Journal of Economics 16, 167-183.

Chan, B.Y. and T. Khoo, 1998, An Analysis of the Deposit-Taking Market of Hong Kong, Review of Industrial Organization 13, 651-667.

Consumer Council, 1994, Are Hong Kong Depositors Fairly Treated? A Summary and Conclusion Prepared by the Consumer Council Steering Group on Financial Services Based on the Consultants Report "An Evaluaion of the Banking Policies and Practices in Hong Kong - Focusing on their Impacts on Consumers" (Government Printer, Hong Kong).

Dann, L. Y. and C. James, 1982, An Analysis of the Impact of Deposit Rate Ceilings on the Market Value of Thrift Institutions, Journal of Finance 37, 1259-1275.

Flannery, M. and C. James, 1984, The Effect of Interest Rate Changes on the Common Stock Returns of Financial Institutions, Journal of Finance 39, 1141-1153.

Hong Kong Monetary Authority, 1994, Study on the Consumer Council Report "Are Hong Kong Depositors Fairly Treated?" (Government Printer, Hong Kong).

Hong Kong Monetary Authority, 1999, Policy Response to the Banking Sector Consultancy Study.

Jordan, W. A., 1972, Producer Protection, Prior Market Structure and the Effects of Government Regulation, Journal of Law and Economics 15, 151-176.

KPMG/Barents Group, 1998, Hong Kong Banking Sector Consultancy Study: Hong Kong Banking into the New Milliennium.

Kwan, S., 1991, Re-examination of Interest Rate Sensitivity of Commercial Bank Stock Returns Using the Random Coefficient Model, Journal of Financial Services Research 5, 61-76.

Millon-Cornett, M.H. and H. Tehranian, 1989, Stock Market Reactions to the Depository Institutions Deregulation and Monetary Control Act of 1980, Journal of Banking and 
Finance 13, 81-100.

Peltzman, S., 1976, Toward a More General Theory of Regulation, Journal of Law and Economics 19, 211-240.

Saunders, A. and M. Smirlock, 1987, Intra- and Inter-industry Effects of Bank Securities Market Activities: The Case of Discount Brokerage, Journal of Financial and Quantitative Analysis 22, 467-482.

Schipper, K. and R. Thompson, 1983, The Impact of Merger Related Regulations on the Shareholders of Acquiring Firms, Journal of Accounting Research 21, 184-221.

Song, F.M., 1994, A Two-Factor ARCH Model for Deposit-Institution Stock Returns, Journal of Money, Credit, and Banking 26, 323-340.

Stigler, G. J., 1971, The Theory of Economic Regulation, The Bell Journal of Economics and Management Science 2, 3-21.

Sundaram, S., N. Rangan and W. N. Davidson III, 1992, The Market Valuation Effects of the Financial Institutions Reform, Recovery and Enforcement Act of 1989, Journal of Banking and Finance 16, 1097-1122.

Zellner, A., 1962, An Efficient Method of Estimating Seemingly Unrelated Regressions and Tests for Aggregation Bias, Journal of American Statistical Association 57, 348-368. 
Appendix 1

\title{
List of Sample Banks
}

\author{
Bank of East Asia Limited \\ Citi Ka Wah Bank Limited \\ Dah Sing Bank Limited \\ Dao Heng Bank Limited \\ First Pacific Bank Limited \\ HSBC Corporation, Limited \\ Hang Seng Bank Limited \\ Hong Kong Chinese Bank Limited \\ International Bank of Asia \\ Liu Chong Hing Bank Limited \\ Union Bank of Hong Kong Limited \\ Wing Hang Bank Limited \\ Wing Lung Bank Limited
}




\title{
Table 1
}

\section{Event Descriptions}

\author{
Stage One of the Interest Rate Rules Deregulation:
}

(1) 02-28-94 The Consumer Council released the report "An Evaluation of the Banking Policies and Practices in Hong Kong”

(2) 07-04-94 The Hong Kong Monetary Authority (HKMA) released the "Study on the Consumer Council Report: Are Hong Kong Depositors Fairly Treated?"

(3) 07-26-94 The Hong Kong government officially adopted HKMA's study in response to Consumer Council's report on the Interest Rate Rules (IRRs).

(4) 08-26-94 Hong Kong Association of Banks (HKAB) announced a program for the removal of time deposits from the IRRs starting from October 1, 1994.

(5) 03-14-95 The HKMA postponed the third phase of deregulation of time deposits.

(6) 09-26-95 In announcing the removal of interest rate cap on time deposits fixed for 7 days, the government decided that there should be no further move below 7 days and that the current program of deregulation should come to an end.

Stage Two of the Interest Rate Rules Deregulation:

(1) 12-18-98 The HKMA released the commissioned study, "Hong Kong Banking into the New Millennium," which recommended the phased deregulation of the remaining IRRs.

(2) 07-14-99 The HKMA issued a policy initiative to adopt a two-phase approach to deregulate the remaining interest rate rules.

(3) 05-30-00 The HKMA announced the deregulation of the remaining IRRs on time deposits with maturity of less than 7 days, savings deposits, and demand deposits. 


\section{Table 2}

Summary Statistics for the Sample Hong Kong Banks as of 1999

\begin{tabular}{|l|c|c|c|}
\hline & Mean & Median & $\begin{array}{c}\text { Standard } \\
\text { Deviation }\end{array}$ \\
\hline Total Assets $^{1}$ & 200,955 & 48,783 & 424,195 \\
\hline Deposit-Asset Ratio & $80.8 \%$ & $83.0 \%$ & $6.4 \%$ \\
\hline Net Interest Margin & & $2.63 \%$ & $0.40 \%$ \\
\hline Deposit Growth $^{3}$ & $2.61 \%$ & $71.5 \%$ & $31.4 \%$ \\
\hline Loan Growth $^{4}$ & $79.7 \%$ & $75.3 \%$ & $31.2 \%$ \\
\hline $\mathrm{N}$ & $81.5 \%$ & 13 & \\
\hline
\end{tabular}

${ }^{1}$ In million of Hong Kong Dollars.

${ }^{2}$ Defined as the ratio of net interest income to total earning assets.

${ }^{3}$ Calculated as the 5-years compound average growth rate of total deposits.

${ }^{4}$ Calculated as the 5-year compound average growth rate of total loans. 
Table 3

Regression Estimates of Abnormal Returns for the Sample of 13 Publicly Traded Commercial Banks in Hong Kong September 1993 to October 1995

\begin{tabular}{|c|c|c|c|c|c|c|}
\hline \multirow[b]{2}{*}{ Events } & \multicolumn{4}{|c|}{ AR (Abnormal Returns) ${ }^{a}$} & \multicolumn{2}{|c|}{ F-statistics ${ }^{b}$} \\
\hline & Mean & $\begin{array}{l}\text { Student's } \\
\text { t-statistics }\end{array}$ & Median & $\begin{array}{l}\text { Signed- } \\
\text { Rank } \\
\text { statistics }\end{array}$ & $\begin{array}{c}\mathrm{H}_{\mathrm{o}}: \mathrm{AR}_{\mathrm{i}}=\mathrm{AR}_{\mathrm{j}}=0 \\
\forall \mathrm{i} \neq \mathrm{j}\end{array}$ & $\begin{array}{c}\mathrm{H}_{\mathrm{o}} \text { : Conditioning } \\
\text { on size, } \mathrm{AR}_{\mathrm{i}}=\mathrm{AR}_{\mathrm{j}} \\
\forall \mathrm{i} \neq \mathrm{j}\end{array}$ \\
\hline $\begin{array}{l}\text { (1) 02-28-94: Consumer Council } \\
\text { released the Report on IRRs }\end{array}$ & $-1.71 \%$ & $-1.84 *$ & $-1.47 \%$ & -19 & $6.57 * * *$ & $5.81 * * *$ \\
\hline $\begin{array}{l}\text { (2) 07-04-94: HKMA relerased its } \\
\text { own study of IRRs }\end{array}$ & $0.26 \%$ & 0.68 & $0.30 \%$ & 9 & 0.85 & 0.92 \\
\hline $\begin{array}{l}\text { (3) 07-26-94: HK government } \\
\text { adopted HKMA study }\end{array}$ & $0.98 \%$ & 1.53 & $0.03 \%$ & 8 & 1.51 & 1.52 \\
\hline $\begin{array}{l}\text { (4) 08-26-94: HKAB relaxed IRR on } \\
\text { long-term time deposits }\end{array}$ & $-0.13 \%$ & -0.25 & $-0.50 \%$ & -9 & $1.66^{*}$ & $1.83^{*}$ \\
\hline $\begin{array}{l}\text { (5) 03-14-95: HKMA postponed } \\
\text { IRRs deregulation }\end{array}$ & $0.49 \%$ & 1.06 & $0.44 \%$ & 12 & 0.97 & 0.96 \\
\hline $\begin{array}{l}\text { (6) 09-26-95: HK government } \\
\text { terminated IRRs deregulation }\end{array}$ & $0.61 \%$ & 1.44 & $0.61 \%$ & $21 *$ & 1.06 & 1.05 \\
\hline$(1)+(2)+(3)+(4)$ & $-0.60 \%$ & -0.43 & $-2.71 \%$ & -7 & $1.63 *$ & $1.67 *$ \\
\hline$(5)+(6)$ & $1.10 \%$ & 1.57 & $0.33 \%$ & 14 & 1.35 & 1.26 \\
\hline$(1)+(2)+(3)+(4)+(5)+(6)$ & $0.50 \%$ & 0.47 & $0.72 \%$ & 4 & 0.71 & 0.78 \\
\hline
\end{tabular}




\section{Notes to Table 3:}

$* * *, *$ indicate significance at the $1 \%$ and $10 \%$ levels, respectively.

${ }^{a}$ These are the multivariate regression estimates of the event dummy coefficients for individual banks using seemingly unrelated regression of daily stock returns on market returns, lagged market returns, relative changes in 12-month HIBOR, lagged interest rate changes, and dummy variables corresponding to the six events.

${ }^{b}$ The F-test for the last three rows applies to the sum of the abnormal returns. Conditioning on the deposit-to-asset ratio yields qualitatively similar results. 
Table 4

Regression Estimates of Abnormal Returns for the Sample of 13 Publicly Traded Commercial Banks in Hong Kong July 1997 to June 2000

\begin{tabular}{|c|c|c|c|c|c|c|}
\hline \multirow[b]{2}{*}{ Events } & \multicolumn{4}{|c|}{ AR (Abnormal Returns) ${ }^{a}$} & \multicolumn{2}{|c|}{ F-statistics ${ }^{b}$} \\
\hline & Mean & $\begin{array}{l}\text { Student's } \\
\text { t-statistics }\end{array}$ & Median & $\begin{array}{l}\text { Signed- } \\
\text { Rank } \\
\text { statistics }\end{array}$ & $\begin{array}{c}\mathrm{H}_{\mathrm{o}}: \mathrm{AR}_{\mathrm{i}}=\mathrm{AR}_{\mathrm{j}}=0 \\
\forall \mathrm{i} \neq \mathrm{j}\end{array}$ & $\begin{array}{c}\mathrm{H}_{\mathrm{o}} \text { : Conditioning } \\
\text { on size, } \mathrm{AR}_{\mathrm{i}}=\mathrm{AR}_{\mathrm{j}} \\
\forall \mathrm{i} \neq \mathrm{j}\end{array}$ \\
\hline $\begin{array}{l}\text { (1) 12-18-98: HKMA released } \\
\text { commissioned study on HK banking }\end{array}$ & $-2.02 \%$ & $-4.65 * * *$ & $-2.14 \%$ & $-42.5 * * *$ & 0.42 & 0.46 \\
\hline $\begin{array}{l}\text { (2) 07-14-99: HKMA responded to } \\
\text { the commissioned study }\end{array}$ & $1.34 \%$ & $2.23 * *$ & $1.06 \%$ & $26.5^{*}$ & 0.41 & 0.43 \\
\hline $\begin{array}{l}\text { (3) 05-30-00: HKMA announced } \\
\text { deregulation of remaining IRRs }\end{array}$ & $-3.34 \%$ & $-5.34 * * *$ & $-3.61 \%$ & $-38.5 * * *$ & $1.95 * *$ & 0.87 \\
\hline$(1)+(2)+(3)$ & $-4.01 \%$ & $-5.82 * * *$ & $-3.64 \%$ & $-45.5 * * *$ & 0.90 & 0.46 \\
\hline
\end{tabular}

$* * *, * *, *$ indicate significance at the $1 \%, 5 \%$, and $10 \%$ levels, respectively.

a These are the multivariate regression estimates of the event dummy coefficients for individual banks using seemingly unrelated regression of daily stock returns on market returns, lagged market returns, relative changes in 12-month HIBOR, lagged interest rate changes, and dummy variables corresponding to the three events.

${ }^{b}$ The F-test for the last three rows applies to the sum of the abnormal returns. Conditioning on the deposit-to-asset ratio yields qualitatively similar results. 